\title{
The Importance of Reliever Airports in the USA
}

\author{
David A. NewMyer, Mark C. Modjeski, John K. Voges, and Justin T. Bryant \\ Southern Illinois University Carbondale
}

\begin{abstract}
The purpose of this study was to (1) conduct a literature review of reliever airports with a focus on historical reliever airport funding, including the importance of reliever airports and reliever airport employment; and (2) to conduct a survey of reliever airports to determine (A) the total number of employees directly employed by the operating entities; and (B) a total on-airport employment estimate. The economic impacts of reliever airports will be reviewed in order to provide information to policy makers about the importance of reliever airports from an employment perspective. The literature review found little existing data pertaining to reliever airport employment. Additionally, the currency of the data could not be reliably verified. Reliever airports surveyed in this research are those designated as reliever airports by the Federal Aviation Administration in a document entitled "National Plan of Integrated Airport Systems." A total of 253 of 278 designated reliever airports were contacted via mail and afforded the opportunity to participate in the survey. A total of 25 reliever airports were not included in the study due to a lack of contact information or change in airport status. Responses from 197 (77.9 \% of those contacted) airports were received at the completion of the data collection period. Survey results indicate that respondents reported 2,906 full-time operating entity employees, 419 part-time operating entity employees, and 95,489 total on-airport employees. Additionally, the ten airports that reported the highest number of operating entity employees comprise $45.7 \%$ of all responding reliever airport operating entity employees. The ten airports that reported the highest number of on-airport employees comprise $57.7 \%$ of all responding reliever on-airport employees.
\end{abstract}

\section{INTRODUCTION}

The Federal Aviation Administration's (FAA) aerospace forecast for FY 2006-2017 indicates that the general aviation fleet will grow $1.4 \%$ annually during the 12-year forecast period (FAA, 2005, p. 20). This 12-year forecast also indicates a yearly increase of $3.2 \%$ in the number of general aviation hours flown. Serving this demand are 19,596 airports in the United States (FAA, 2004, p. 1). Of these 19,596 airports, the Federal Aviation Administration's National Plan of Integrated Airport Systems (NPIAS) distinguishes 3,444 selected airports as being vital to the nation's transportation infrastructure, and these airports are eligible to receive federal funding via the Airport Improvement Program (AIP). Of the 3,444 existing NPIAS airports, 278 are designated as reliever airports. Reliever airports are defined as "specialized high capacity general aviation airports whose purpose is to ease congestion at hub airports." Relievers must have more than 100 based aircraft and/or more than 25,000 annual itinerant operations (FAA, 2004, p. 8). Reliever airports are not only economic forces in their own respect, their symbiotic relationship with hub airports implies their role as an economic multiplier.

Reliever airports play a vital role in the aviation industry's infrastructure; historically, however, their importance has been questioned. In 1994, the General Accounting Office (GAO) released a report entitled "Airport Improvement Program: Reliever Airport Set-Aside Funds Could Be Redirected." The key point to this report is that "...conditions under which the reliever set-aside was created to address, do not exist today; largely because of a long and steady decline in general aviation traffic-a trend unforeseen when the set-aside was created" (GAO, 1994, p. 1). The report further states that, “... the [FAA] has not done any detailed studies or analyses to identify which relievers contribute to the national airport system" (GAO, 1994, p. 2). In addition, there are questions about general aviation and reliever airport funding being raised in the reauthorization of the Airport Improvement Program in FY 2007. 
More recently, in the October 18, 2006 CRS report entitled "Reauthorization of the Federal Aviation Administration: Background and Issues for Congress," discretionary fund setasides have again been scrutinized. Set-asides for reliever airports, the Military Airports Program (MAP), and the capacity/safety/security/noise program are all subject to alteration (CRS, 2006, p. 26). The Air Transport Association (ATA) has argued that non-commercial service airports currently receive funding that could better be obtained from user taxes (CRS, 2006, p. 26).

With policy makers questioning the importance of reliever airports, a study of their vital role is warranted. This data is necessary in defining the reliever airports distinctive role in the aviation industry. Therefore the purposes of the study are:

1. To conduct a literature review of reliever airports with a focus on historical reliever airport funding, including the importance of reliever airports and reliever airport employment. Also, to assess the economic impacts of reliever airports in order to provide information to policy makers about the importance of reliever airports from an employment perspective.

2. To conduct a survey of reliever airports to determine (A) the total number of employees directly employed by the operating entities; and (B) a total onairport employment estimate.

\section{DEFINITIONS}

\section{Evolution of Reliever Airport Definitions}

Historically, reliever airports were first defined in the National Airport Plan (NAP). In subsequent years, the definition has undergone change under the NAP, the National Airport System Plan (NASP), and finally the NPIAS. The following is a chronological anthology of those definitions:

- NAP - a general aviation airport that will "serve to divert a substantial degree of general aviation traffic from a congested airline served airport” (USDOT, 1966/67, p. 18).
- NASP - an "airport whose primary purpose is to serve general aviation and, at the same time, relieve congestion at a major airport having a high density of scheduled airline traffic (including military, if appropriate) by attracting and diverting general aviation traffic away from the major airport to the airport providing relief” (USDOT, 1972, p. 23).

- NPIAS - a "specialized airport which provides pilots with attractive alternatives to using congested hub airports" (FAA, 2004, p. 8).

By means of the NPIAS, the FAA designates certain airports as being important in meeting present and anticipated needs regarding civil aviation, national defense, and the postal service (FAA, 2004, p. 4). With their importance recognized, NPIAS airports are entitled to a portion of funding through the AIP. Commercial service, reliever, and general aviation airports must meet certain entry criteria in order to receive funding. The section below outlines the entry requirements for reliever airports receiving two-thirds of the $1 \%$ allotted appropriations when total AIP funding is above the required level for the fiscal year. In order to receive the allotted monies the airport must:

- Have 100 based aircraft.

- Have more than 75,000 annual operations.

- Have a runway with a minimum usable landing distance of 5,000 feet.

- Have a precision instrument landing procedure.

- Have at least 20,000 hours of annual delays in commercial passenger aircraft takeoffs and landings at the airport relieved (FAA, 2005, p. 11).

The main function of a reliever airport is to provide general aviation traffic with an alternative airport near a commercial service airport, thereby easing congestion at commercial service airports. 


\section{METHODOLOGY}

The purpose of this study is to establish a base figure of employment at reliever airports in the United States. As a result of the increased amount of traffic that the U.S. National Airspace System is experiencing, reliever airport employment data are essential. Due to the broad scope of the topic, a general survey instrument was prepared and administered. To facilitate the search for reliever airport employment data adequate to the direction of this study, the following methods were incorporated:

- Mass mailed a six-question airport employment survey instrument.

- Organized and filed responses according to date of mailing.

- Recorded data in a Microsoft Excel database involving many individual spreadsheets.

- Reviewed journals and studies on aviation industry employment data and statistics.

- Explored and evaluated reliever airport and aviation employment material from Internet Web sites and pages.

In preparation for this study, a review of airport employment literature was performed in order to assess the need for expanded research. The literature review provided:

- Employment numbers for airport operating entities and total on-airport employment.

- Historical legislation and funding procedures.

- Nationally-based employment studies involving reliever airport employment.

The official websites of reliever airports were also reviewed. However, there were not many that existed, and success in finding airport employment numbers was minimal. Airport websites also lacked dated material; no reliable method of extracting data within a given time frame was available. The FAA's NPIAS list of airports is the original source used for the list of reliever airports. A total of 278 reliever airports were listed in this report, according to their 2004 estimate. However, in their list of airports, only 260 were found (FAA, 2004).

Resources from the National Airport Safety Data Collection Program at SIUC provided a means to gather contact names and addresses for the reliever airports from the GCR \& Associates, Inc. (GCR) / FAA 5010 database. In retrieving the contact information, seven airports were not found in the database. Those airports were Troy-Oakland, Berz-Macomb, Angola, Lancaster, Wallkill, Wings Field, and Rostraver; this reduced the total number of airports to be contacted in the survey to 253.

In order to collect data specific to this area of research, airport-entity personnel at reliever airports had to be contacted. Before facilitating this process, permission was requested from the Southern Illinois University Carbondale (SIUC) Human Subjects Committee. It is SIUC research policy to apply for such permission via a special application when conducting research involving human subjects. An extension of approval was granted on December 15, 2005, effective through March 31, 2006, the last day of mailings.

The first mailings were sent out just two days before Christmas 2005. Data collection began shortly thereafter and continued through April 25, 2006; a period of approximately five months. Throughout the data collection period, there were a total of three mass mailings; 253 packages were sent the first time, with mailings reduced subsequently based on those returned. The entire package included a signed cover letter explaining the purpose of the study, the survey instrument (see Appendix A), and a selfaddressed postage-paid envelope.

A spreadsheet containing the data was consistently updated as responses were returned. A second mailing was completed during the week of February 9, 2006. The third and final mailing was sent on March, 31 2006. Reliever airport personnel were afforded the option to respond to these mailings by mail, fax, e-mail, or phone. The majority of the responses were returned by mail. Representatives at twelve airports responded by fax and data for two airports were received by e-mail.

Data collection was completed during the week of April 21, 2006. The study had an above average response rate of $77.9 \%$. Out of the 253 
total reliever airports surveyed, 197 responses were received, with 56 non-responses.

\section{Assumptions and Guidelines Used in Analysis}

To ensure an orderly study, the following principles were used when recording returned responses:

1. Unless otherwise noted by the respondent, the employment figures provided were believed to be current as of the day the questionnaire was returned and inputted.

2. When involving a range rather than a single figure, the low employment estimate was used.

3. When more than one questionnaire was returned in a succeeding mailing from any one reliever airport, the previouslyreturned questionnaire was used.

4. Numbers from on and off-airport personnel were included in the total airport employment estimate.

\section{Limitations}

Characteristic of any study, there are limitations to the research, retrieval process, and analysis of the results. Below are some of these limitations.

1. With a retrieval period of roughly four and a half months, a $100 \%$ response rate was not expected.

2. The FAA's Report to Congress 20052009 did not have an accurate, up-todate list of reliever airports, thus affecting the total number of airports included in this study.

3. Seven airports listed in the 2005-2009 report were immediately excused from the study, because their addresses could not be found on the GCR / FAA 5010 database. This could be due to the lack of reporting airport closures, and/or changes in the airport identifier code.

4. Responses were self-reported, with no way for those conducting the survey to verify the accuracy.

5. An "unknown" response, as reported in the survey, was entered as a "zero" when entering the data.

\section{RELIEVER AIRPORT EXAMPLES, FUNDING, AND EMPLOYMENT}

Though the 278 reliever airports represent less than one-tenth of the airports included in the NPIAS, 29\% of the nation's general aviation fleet is based at reliever airports (FAA 2004, p. 8). Additionally, over half of the nation's population resides within 20 miles of a reliever airport (FAA, 2004, p. 6).

Though the parameters presented in the Definitions section are very precise, reliever airports that meet these criteria vary. For example, Merrill Field, a reliever for Anchorage International Airport, has 1,052 based aircraft and nearly 200,000 local and itinerant annual operations (Form 5010-1, 2006). Fort Lauderdale Executive Airport proclaims itself to be the eighth busiest general aviation airport in the U.S. based on itinerant operations (City of Ft. Lauderdale, 2006). The airport is home to six fixed-base operators and a 200-acre industrial airpark. Palwaukee Airport, located outside of Chicago, Illinois, provides relief to the O'Hare International Airport, one of the busiest airports in the world. Seventy years ago Palwaukee was a 40-acre grassy plain with dirt runways (Palwaukee Municipal Airport, 2006). Ohio State University Airport is the nexus of the university's aviation program. Along with being designated as a reliever for Port Columbus International Airport, the university's airport provides \$103.5 million in direct and indirect benefits to the state (Ohio State University 2006). Reno Stead Airport, Located in Nevada, is home to the world famous National Championship Air Races. Reno Stead Airport is a reliever for Reno-Tahoe International Airport (Reno-Tahoe International Airport, 2006).

Each of these airports plays a distinctive and very important role outside of functioning as a reliever to their congested counterparts. Students, businesses, and aviation enthusiasts in general all benefit from reliever airports.

\section{Funding History of Reliever Airports}

Funding for airports today is provided through the AIP. The origins of the AIP can be traced back to the post World War II era, and the Federal-Aid Airport Program (FAAP) (FAA, AIP, 2006). The FAAP received its 
authorization from the Federal Airport Act of 1946, and received its allocations from the general fund of the U.S. Treasury (FAA, AIP, 2006).

A key piece of legislation that impacted funding at reliever airports was the Airport and Airway Development Act of 1970 (AADA). Revenues from aviation-user taxes (fuel, airline fares, etc.) were placed into the Airport and Airway Trust Fund (AATF). This fund then issued grants to airports through the Planning Grant Program (PGP) and the Airport Development Aid Program (ADAP). During an 11-year period of issuing grants $\$ 4.5$ billion was approved. The ADAP funded reliever airports in the amount of $\$ 61.5$ million over the six-year period of 1970-1975, annually averaging a little over \$10 million per year (ADAP, 1976).

During the 1980s and 1990s, reliever setaside amounts peaked, reaching to $10 \%$ of all AIP funds, which amounted to $\$ 160$ million per year. These set-aside amounts remained until 1994. In that year the GAO released a report entitled "Reliever Airport Set-Aside Funds Could Be Redirected.” Some of the conclusions of the report were:

- Conditions that justified the set-aside for reliever airports do not exist today (GAO, 1994, p. 1).

- General aviation traffic is not significantly responsible for congestion and delays at major airports (GAO, 1994, p. 1)

- There is an "oversupply" of capacity for general aviation traffic at many reliever airports (GAO, 1994, p. 13).

Pursuant to this report, the set-aside funds for reliever airports were reduced to $\$ 40$ million in 1994-1995, and \$48 million in 1996 (GAO, 1996, p. 5). Even with the reduction in set-aside funds, reliever airports received funds in excess of \$100 million per year during the 1994-1998 time periods (FAA, 1998). This trend is contrary to the conclusions of the GAO report. Reliever airports continued to receive significant AIP funding.

Since 1994, reliever airport set-aside funds have endured a cyclic phase of reductions and removals. In 2000, the Wendell H. Ford Aviation Investment and Reform Act for the $21^{\text {st }}$
Century was passed by Congress. Also known as Air 21, this act reinstated reliever set-aside funds. Under Air 21 reliever airports were entitled to $0.66 \%$ of discretionary funds if the amount of total AIP funding was greater than or equal to $\$ 3.2$ billion (FAA, AIP Overview, 2005). This sliding scale lasted until 2003 when Vision 100 emerged, eliminating the reliever setasides once again. During this time period reliever airports still received funding in excess of $\$ 100$ million each year.

Figure 1 presents reliever airport AIP funding data for the years 1996-2005 as reported by the FAA. As can be seen in Figure 1, reliever airports continued to receive funding in excess of $\$ 100$ million throughout the decade, with funding levels peaking over \$200 million in both FY 2001 and 2003.

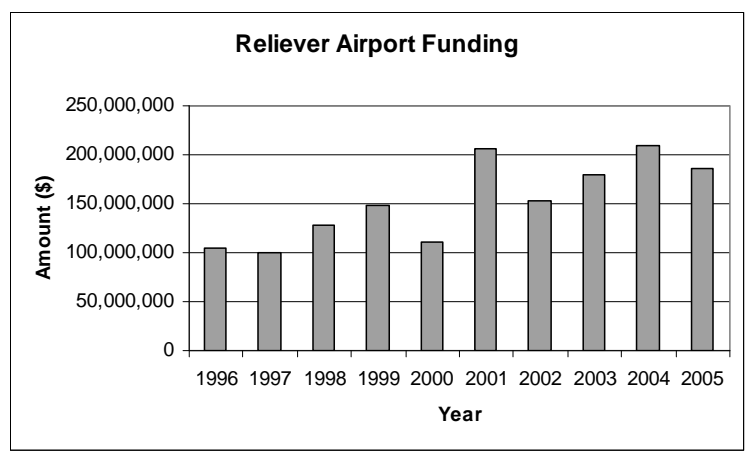

Figure 1. Reliever Airport Funding (FAA, Grant histories, 2006)

Although the importance of reliever airports has been questioned by policy makers, and set-aside funds have been adjusted and removed, reliever airports have continued to receive significant levels of funding.

More funding issues become apparent with the arrival of a new class of aircraft called Very Light Jet's (VLJ's). VLJ's have been envisioned as a mechanism that will link small communities with seamless travel. Yet the utilization of these aircraft is subject to speculation and market forces yet to be realized. It is likely that VLJ's will have substantial impact on the NAS, and specifically on reliever and secondary airports for their service. With that said, historically, fifty percent of all flights performed by aircraft in the light jet category such as Cessna's CJ1,CJ2,CJ3 and the Learjet 35 have at least one end airport in one of sixteen major metropolitan areas throughout the country. It is concluded 
that these destinations will be impacted similarly by the arrival of the 5,000-10,000 additional VLJ aircraft estimated to enter service by the year 2015 (FAA, 2006, Air Traffic Bulletin).

Capacity crisis at certain core airports will occur even without the emergence of this new category of aircraft. Yet with the addition of the VLJ aircraft, a redistribution of traffic is likely. This will place greater emphasis on the role of small, regional airports within these key metropolitan areas. This will create a strengthening for the need of the existing reliever airports as well as the creation of new ones to accommodate the capacity (Bonnefoy \& Hansman, 2005). These accommodations will require set-aside funding.

The FAA is very optimistic in its most recent aviation forecasts which project an average annual growth of $10.2 \%$ in general aviation turbojet activity over the next ten years much of which is anticipated to be driven in large measure by the introduction of this new class of aircraft into the system (CRS Report for Congress, 2006).

This emerging market of new aircraft will add additional pressure on the NAS and additional capacity to the destination airports. Emerging operators, such as the Florida based DayJet and PogoJet, will utilize these new aircraft and will be operated under existing Part 135 Air Taxi rules. Success of these types of operators will likely influence the type of pressure exerted on their departure and destination airports.

"If the utilization of VLJs is predominantly accounted for by individual owners, corporations, and fractional ownership programs, then VLJs may have a more substantial impact on general aviation reliever airports. If, on the other hand, a large number of VLJs are used for air-taxi service with connectivity to commercial air carrier networks, then the VLJ impact could exacerbate concerns over congestion and delay at larger commercial airports," (CRS Report for Congress, 2006).

No employment data is available on the prospective employment numbers associated with VLJ's.

\section{Reliever Airport Employment}

Economic impact studies are often conducted at various airports in the airport system. Economic impact is based on "the theory that a dollar flowing into a local economy from outside of the economy is a net benefit, and measures of new economic benefits that accrue to the region due to the airport that would not have otherwise occurred" (Economic Impact Model-General Aviation, 2005). Economic impact studies allow multiple layers of government to fiscally compare airports with other public projects (Economic Impact ModelGeneral Aviation, 2005). One of the required variables for this process is on-airport employment.

Reliever airports not only ease congestion at commercial service airports, they also have an economic presence. Geographically, reliever airports frequently are clustered near larger metropolitan areas with a commercial service airport in the close vicinity. The location of reliever airports near the commercial service airport being relieved also places them near high concentrations of nation-wide employment. As previously stated, $57.45 \%$ of the nation's population resides within 20 miles of a reliever airport. Considering the potential economic impact of reliever airports, and their historically questioned importance, an analysis of employment factors for reliever airports is considered important research that adds to the literature of the debate related to their importance.

This study will differentiate between persons employed directly by the airport (operating entity) and total on-airport (nonoperating entity plus operating entity) employees. Preparation for this study includes a review of reliever airport data that are currently available. Three types of sources will be reviewed:

- Sources that provide employment numbers of the operating entity.

- Sources that provide employment numbers for total on airport employment.

- National industry employment studies that involve reliever airports. 


\section{State, Local, and Individual Airport Sources}

The jurisdiction of an airport operating entity traditionally lies with, but not limited to, the city, county, port district or authority, airport district or authority, private, and/or state entity (NewMyer, Korir, \& Mehta, 2005). These classifications suggest possible sources for employment data which may include local or state governments, and individual airport websites and employment studies.

The Arizona Department of Transportation website (www.az.dot.gov) offers a link to economic impact studies of Arizona airports. These studies provide information on the total economic impact of the airport, total employment, and payroll amounts. For example, the economic impact study of Chandler Municipal Airport indicates 246 employees with an annual payroll of $\$ 5.1$ million (Arizona Department of Transportation, Economic impact and aviation services, 1998). However, no segregation between peripheral and operating entity employment is made. What this data does show is Arizona's recognition of the impact aviation has on the overall economy of the state.

The Minnesota Department of Transportation's website (www.dot.state.mn.us) offers an economic calculator, with which various data for the airport can be entered and economic impact is estimated. No viable reliever airport employment data is available.

The California Department of Transportation (www.dot.ca.gov) released an economic study which concluded that aviation accounted for $9 \%$ of the state's employment and $9 \%$ of the gross state product. This study estimates that there are 271,800 aviation-related jobs in California; however no estimate of reliever airport employment is provided (California Department of Transportation, Aviation in California, 2003).

An economic study completed by the state of Illinois offers the economic impact of Illinois airports on an airport by airport basis. This study offers a full and part-time employment figure for each airport. For example, Palwaukee Municipal Airport has 337 full-time jobs and 64 part-time jobs. This study, updated in 2004, does not differentiate between operating entity employees and total on-airport employees (Jamison, 2004).
Some individual airport websites list total employment numbers for the airport, but few offer exact numbers of operating entity employment. Many airport websites offer no data on airport employment, and many reliever airports do not have websites. There is no method of extracting national reliever airport employment data by way of individual airport websites, or by state department of transportation economic analysis.

\section{National Employment Studies}

The Bureau of Labor Statistics (BLS) offers employment data by industry. Until 1997, the BLS published this data by Standard Industry Classification (SIC). This system was replaced by the North American Industry Classification System (NAICS), which includes employment data from Canada and Mexico. The NAICS consists of 20 sectors of industry. Sector 48 includes the transportation industry. Support activities for transportation are located in section 488, and airport operations are located in sector 48811. Below are two definitions of sectors relevant to airport employment:

- $\quad$ NAICS definition of sector 48811; Airport Operations -“This industry comprises establishments primarily engaged in (1) operating international, national, or civil airports or public flying fields, or (2) supporting airport operations (except special food services contractors), such as rental of hangar space, air traffic control services, baggage handling services, and cargo handling services” (BLS, NAICS Definitions, 2004).

- NAICS definition of sector 488119; Other Airport Operations -“This U.S. industry comprises establishments primarily engaged in (1) operating international, national, or civil airports, or public flying fields or (2) supporting aircraft operations, such as rental of hangar space, and providing baggage handling and/or cargo handling services" (BLS, NAICS Definitions, 2004).

Both of these definitions indicated that employment for not only airport operating entities, but also hangar rental, baggage handling, and other on airport employment are 
included. Also, no differentiation for specific reliever airport employment data is available. However, the BLS data does prove useful in displaying the upward trend of airport employment. Employment in sector 48811, airport operations, has increased from 42,900 in 1996 to 68,100 in 2006 (BLS, NAICS, 2006).

The data from the BLS is not specific enough to define reliever airport employment numbers. The data includes all employees at airports, including specifically identified nonoperating entity employment (hangar rental, baggage handling, etc.). Therefore, as defined, this category can include operating entity, airline, and general aviation employment. However, this category of BLS data does indicate an increase in total airport employment.

Other national studies pertaining to airport employment exist. The Airports Council International-North America (ACI-NA) conducted an analysis of both airport operating employment, and total airport related employment. This study estimated 1.9 million airport- related jobs in the United States (ACINA, 2002, p. 1). The American Association of Airport Executives (AAAE) has reported commercial service employment by hub category. Nonetheless, these sources did not specifically address employment figures of reliever airports.

\section{Literature Review Conclusion}

The purpose of this literature review is to provide an answer to several questions: what is a reliever airport; how has the importance of reliever airports been questioned; and how has this affected reliever airport funding? Acknowledging a correlation between employment and economic importance, what employment data exists specifically for reliever airports? This data is necessary in ensuring reliever airports are prepared for future traffic loads. The introduction of VLJs is one factor that must be considered when debating funding levels at reliever airports.

Essentially, the purpose of a reliever airport is to relieve general aviation traffic from nearby commercial service airports. Variances in general aviation traffic forecasts have made reliever airports a target for funding reduction and removal. Despite the varying nature of these set-aside levels, reliever airports have consistently justified funding in an excess of setaside amounts. Employment estimates are necessary in gauging the economic significance of any industry. Though there are some sources that provide airport employment data, no current or specific data exists for reliever airports.

Thus, further employment studies of reliever airports are crucial in providing information as the future importance of reliever airports is considered. This study is directed toward reliever airports, and will differentiate between operating entity employment and total on-airport employment.

\section{SURVEY RESULTS AND ANALYSIS}

\section{Overall Results}

Of the 197 responses received by April 21, 2006, the total operating entity employment as reported by the responding airports was 3,325 operating entity employees. This estimate includes the total full-time operating entity employees and the low estimate for part-time operating employees. Total operating entity employment including the high part-time estimate is 3,329. No variance in full-time operating employment was supplied by the respondents. The variance between the low estimate of part-time employees and the high estimate is negligible.

The total on-airport employment (low estimate) as reported by the respondents is 95,489 employees; the high estimate is 96,139 employees. This category of the survey included persons employed by fixed-base operators, concessions, maintenance/repair organizations, flight training companies, corporate flight departments, and other airport businesses. As with the data for operating entity employees, there is a very small gap between the high and low estimate of employees.

\section{Operating Entity Results}

Reliever airports are operated by a diverse group of operating entities. These groups include (but are not limited to); towns, cities, states, airport authorities, and public universities. The operating entities are diverse; they represent different levels of public and private ownership. The results in this section contain data relating reliever airport employment to operating entity. Of the 197 respondents, 14 different operating 
entities were reported. Figure 2 contains the choices of operating entity offered on the survey. Figure 3 lists the operating entities listed in the "other" block.

The most reported operating entity in this survey is "city," which received a total of 69 (36\%) responses, followed by "county" with 46 (23\%) responses. In the "other" category, which was $3^{\text {rd }}$ overall, $71 \%$ of the respondents reported being operated by a private owner. The only other entity reported under the "other" category that received more than one response was the "town" operating entity, with two responses.

As shown in Figure 4, the operating entity that reported the greatest number of employees was the airport district or authority. This group reported 1,990 full and part-time employees, or $59.8 \%$ of the total. Responding county-operated reliever airports reported the highest total of onairport employees, as shown in Figure 5.

\begin{tabular}{|lc|}
\hline Operating Entity N=197 \\
\hline City & 69 \\
\hline County & 46 \\
\hline Port District or Authority & 10 \\
\hline Airport District or Authority & 32 \\
\hline State & 4 \\
\hline Other & 35 \\
\hline
\end{tabular}

Figure 2. Categories of operating entity responses: Reliever airport survey.

\begin{tabular}{|l|l|}
\hline $\begin{array}{l}\text { Operating Entity } \\
\mathbf{N = 1 9 7}\end{array}$ & $\begin{array}{l}\text { Airports Reporting } \\
\text { This Operating Entity }\end{array}$ \\
\hline Privately Owned & 26 \\
\hline Town & 2 \\
\hline Corporation & 1 \\
\hline Metropolitan Authority & 1 \\
\hline Private Contract to County & 1 \\
\hline Public Building Commission & 1 \\
\hline Public University & 1 \\
\hline Village & 1 \\
\hline Unknown & 1 \\
\hline
\end{tabular}

Figure 3. Categories of other operating entity responses: Reliever airport survey.

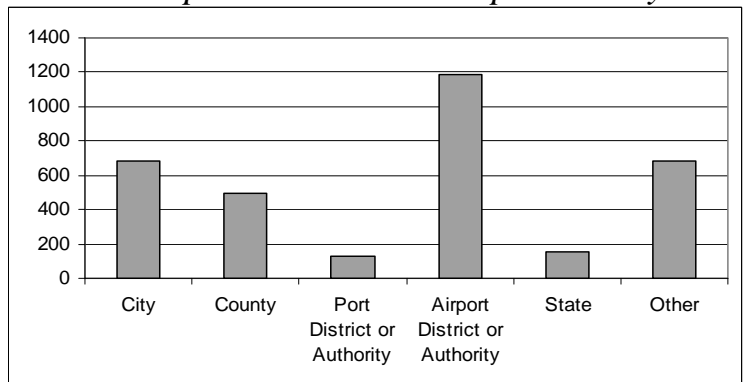

Figure 4. Operating entity employment by category: Reliever airport employment survey

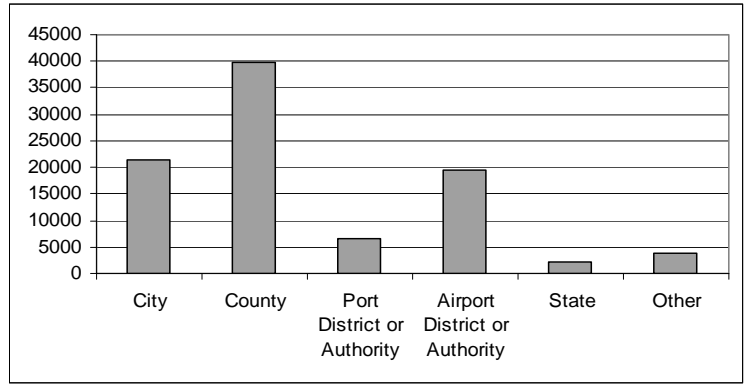

Figure 5. Total on-airport employment by operating entity category: Reliever airport employment survey.

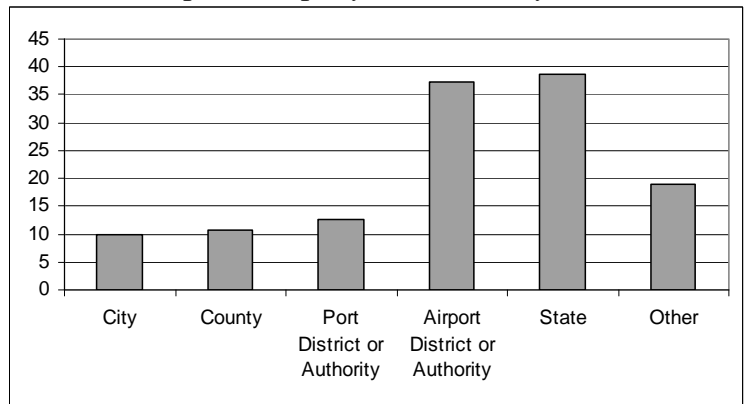

Figure 6. Mean operating entity employment: Reliever airport employment survey.

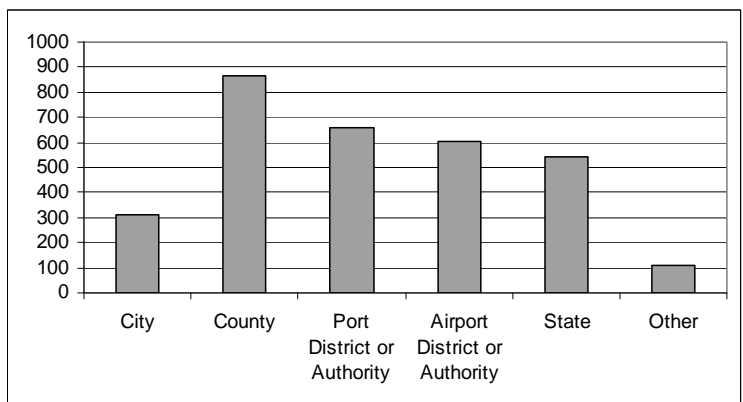

Figure 7. Mean on-airport employment: Reliever airport employment survey

Figure 6 and Figure 7 depict the mean number of operating entity employees, and the mean number of on-airport employees by operating entity. State operating entities have the highest reported mean concentration of operating entity employees at 38.8 operating entity employees per airport, followed closely by airport district or authorities at 37.2 operating entity employees per airport. County operating entities have the highest reported on-airport employee mean concentrations with 866.04 employees per airport.

\section{Top Ten Representational Data}

Figure 8 ranks the top ten airports according to operating entity employment. Note 
that these ten airports employ 1,519 full and part-time operating entity employees. This amount represents $45.7 \%$ of all reliever airport operating entity employees, full and part-time. These reliever airports also account for $36.1 \%$ of the total on airport employees reported in this survey.

Figure 9 ranks the top ten airports according to total on-airport employment. These ten reliever airports have a total on-airport employment number of 55,058. This employment number represents $57.7 \%$ all reported reliever airport employment. These airports also represent $14.3 \%$ of total reported operating entity employment.

The data in figure 10 considers entry criteria for reliever airport funding by sharing the top ten reliever airports ranked by based aircraft. The 8,787 aircraft based at these airports accounts for $14.1 \%$ of all reliever airport based aircraft as reported by the FAA (FAA, 2005, NPIAS List of Airports). These ten reliever airports represent $6.5 \%$ and $13.7 \%$ of operating entity and total on airport employment, respectively.

The top ten reliever airports ranked by operating entity and total on airport employment each consisted of a large quotient of the total reported reliever airport employment categories.

However, total based aircraft located at an airport does not seem to have an important impact on operating entity or total airport employment at reliever airports.

Further analysis of employment data allows for many other important conclusions. Figure 11 identifies significant statistics of reliever airport employment.

\begin{tabular}{|c|c|c|c|c|c|c|c|c|}
\hline Rank & $\begin{array}{l}\text { Loc } \\
\text { ID }\end{array}$ & Airport Name & State & Operating Entity & $\begin{array}{l}\text { Full-time } \\
\text { Operating } \\
\text { Entity } \\
\text { Employment }\end{array}$ & $\begin{array}{l}\text { Part-time } \\
\text { Operating } \\
\text { Entity } \\
\text { Employment } \\
\text { (Low } \\
\text { Estimate) }\end{array}$ & $\begin{array}{l}\text { Part-time } \\
\text { Operating } \\
\text { Entity } \\
\text { Employment } \\
\text { (High } \\
\text { Estimate) }\end{array}$ & $\begin{array}{l}\text { Total on } \\
\text { Airport } \\
\text { Employment }\end{array}$ \\
\hline 1 & $\mathrm{X} 16$ & Vandenberg & FL & $\begin{array}{l}\text { Airport District or } \\
\text { Authority }\end{array}$ & 542 & 0 & 0 & 50 \\
\hline 2 & TPF & Peter O Knight & FL & $\begin{array}{l}\text { Airport District or } \\
\text { Authority }\end{array}$ & 265 & 0 & 0 & 5000 \\
\hline 3 & DKX & $\begin{array}{l}\text { Knoxville Downtown } \\
\text { Island }\end{array}$ & $\mathrm{TN}$ & $\begin{array}{l}\text { Metropolitan } \\
\text { Authority }\end{array}$ & 133 & 16 & 16 & 1800 \\
\hline 4 & S43 & Harvey Field & WA & Privately Owned & 100 & 20 & 20 & 300 \\
\hline 5 & IWA & Williams Gateway & $\mathrm{AZ}$ & $\begin{array}{l}\text { Airport District or } \\
\text { Authority }\end{array}$ & 99 & 2 & 2 & 453 \\
\hline 6 & VNY & Van Nuys & CA & City & 88 & 11 & 11 & 1000 \\
\hline 7 & EVY & Summit Airpark & $\mathrm{DE}$ & Privately Owned & 80 & 1 & 1 & 81 \\
\hline 8 & DPA & Du Page & IL & $\begin{array}{l}\text { Airport District or } \\
\text { Authority }\end{array}$ & 58 & 2 & 2 & 600 \\
\hline 9 & OUN & $\begin{array}{l}\text { University of Oklahoma } \\
\text { Westheimer }\end{array}$ & OK & State & 49 & 5 & 5 & 143 \\
\hline 10 & PAE & $\begin{array}{l}\text { Snohomish County (Paine } \\
\text { Field) }\end{array}$ & WA & County & 45 & 3 & 3 & 25000 \\
\hline \multicolumn{5}{|c|}{ TOTALS } & 1459 & 60 & 60 & 34427 \\
\hline
\end{tabular}

Figure 8. Top ten reliever airports by operating entity employment: Reliever airport employment survey 


\begin{tabular}{|c|c|c|c|c|c|c|c|c|}
\hline Rank & Loc ID & Airport Name & State & $\begin{array}{l}\text { Operating } \\
\text { Entity }\end{array}$ & $\begin{array}{l}\text { Full-time } \\
\text { Operating } \\
\text { Entity } \\
\text { Employees }\end{array}$ & $\begin{array}{l}\text { Part-time } \\
\text { Operating } \\
\text { Entity } \\
\text { Employees } \\
\text { (Low } \\
\text { Estimate) } \\
\end{array}$ & $\begin{array}{l}\text { Part-time } \\
\text { Operating } \\
\text { Entity } \\
\text { Employees } \\
\text { (High } \\
\text { Estimate) } \\
\end{array}$ & $\begin{array}{l}\text { Total on Airport } \\
\text { Employment }\end{array}$ \\
\hline 1 & PAE & Snohomish County (Paine & WA & County & 45 & 3 & 3 & 25000 \\
\hline 2 & DVT & Phoenix - Deer Valley & $\mathrm{AZ}$ & City & 16 & 0 & 0 & 5000 \\
\hline 3 & TPF & Peter O Knight & FL & Airport District & 265 & 0 & 0 & 5000 \\
\hline 4 & FXE & $\begin{array}{ll}\text { Fort } & \text { Lauderdale } \\
\end{array}$ & FL & City & 13 & 1 & 1 & 3534 \\
\hline 5 & VQQ & Cecil Field & FL & Airport District & 7 & 6 & 6 & 3500 \\
\hline 6 & BJC & Jeffco & $\mathrm{CO}$ & County & 20 & 1 & 1 & 3124 \\
\hline 7 & SUS & Spirit of St Louis & MO & County & 22 & 2 & 2 & 3000 \\
\hline 8 & TDZ & Toledo Metcalf & $\mathrm{OH}$ & Port District or & 43 & 0 & 0 & 2900 \\
\hline 9 & APA & Centennial & $\mathrm{CO}$ & Airport District & 19 & 2 & 2 & 2000 \\
\hline 10 & SGJ & St Augustine & FL & $\begin{array}{l}\text { Airport District } \\
\text { or Authority }\end{array}$ & 12 & 0 & 0 & 2000 \\
\hline \multicolumn{5}{|c|}{ TOTALS } & 462 & 15 & 15 & 55058 \\
\hline
\end{tabular}

Figure 9. Top ten airports by total on-airport employment: Reliever airport employment survey

\begin{tabular}{|c|c|c|c|c|c|c|c|c|}
\hline Rank & $\begin{array}{l}\text { Loc } \\
\text { ID }\end{array}$ & Airport Name & State & Based Aircraft & $\begin{array}{l}\text { Full-time } \\
\text { Operating } \\
\text { Entity } \\
\text { Employment }\end{array}$ & $\begin{array}{l}\text { Part-time } \\
\text { Operating } \\
\text { Entity } \\
\text { Employment } \\
\text { (Low } \\
\text { Estimate) } \\
\end{array}$ & $\begin{array}{l}\text { Part-time } \\
\text { Operating } \\
\text { Entity } \\
\text { Employment } \\
\text { (High } \\
\text { Estimate) } \\
\end{array}$ & $\begin{array}{l}\text { Total on } \\
\text { Airport } \\
\text { Employment }\end{array}$ \\
\hline 1 & MRI & Merrill Field & AK & 1,052 & 10 & 0 & 0 & 250 \\
\hline 2 & FFZ & Falcon Field & $\mathrm{AZ}$ & 1,005 & 10 & 0 & 0 & 10 \\
\hline 3 & DVT & Phoenix - Deer Valley & $\mathrm{AZ}$ & 999 & 16 & 0 & 0 & 5000 \\
\hline 4 & $\mathrm{CNO}$ & Chino & CA & 915 & 10 & 0 & 0 & 300 \\
\hline 5 & FXE & Fort Lauderdale Executive & FL & 915 & 13 & 1 & 1 & 3534 \\
\hline 6 & VNY & Van Nuys & CA & 834 & 88 & 11 & 11 & 1000 \\
\hline 7 & ADS & Addison & $\mathrm{TX}$ & 794 & 12 & 0 & 0 & 200 \\
\hline 8 & SEE & Gillespie Field & $\mathrm{CA}$ & 791 & & & & \\
\hline 9 & PTK & Oakland - Pontiac & MI & 772 & 18 & 7 & 7 & 800 \\
\hline \multirow[t]{2}{*}{10} & APA & Centennial & $\mathrm{CO}$ & 710 & 19 & 2 & 2 & 2000 \\
\hline & & TOTALS & & 8,787 & 196 & 21 & 21 & 13094 \\
\hline
\end{tabular}

Figure 10. Top ten airports by based aircraft: Reliever airport employment survey

\begin{tabular}{|l|l|l|l|}
\hline & $\begin{array}{l}\text { Total On- } \\
\text { Airport } \\
\text { Employment }\end{array}$ & $\begin{array}{l}\text { Operating } \\
\text { Entity } \\
\text { Employment/ } \\
\text { Full-Time }\end{array}$ & $\begin{array}{l}\text { Operating } \\
\text { Entity } \\
\text { Employment/ } \\
\text { Part-Time }\end{array}$ \\
\hline N Valid & 197 & 197 & 197 \\
Missing & 63 & 63 & 63 \\
Mean & 484.72 & 14.75 & 2.13 \\
Median & 100.00 & 5.00 & 1.00 \\
Mode & 100 & 1 & 0 \\
Minimum & 0 & 0 & 0 \\
Maximum & 25000 & 542 & 26 \\
Sum & 95489 & 2906 & 419 \\
\hline
\end{tabular}

Figure 11. Statistics

Multiplying the mean for each category by the total number of reliever airports (278) provides an estimate for reliever airport employment. The total on-airport employment estimate is 134,752 , the total full-time operating entity is 4,100 , and the total part-time operating entity estimate is 592. The combined total of each of these estimates is 139,444 .

The data set includes results from one airport reporting 25,000 on airport employees. This figure far surpasses any other figure reported by respondents, and was treated as an outlier. Figure 12 shows the same statistics for the data set, with the outlier removed.

\begin{tabular}{|l|l|l|l|}
\hline & $\begin{array}{l}\text { Total On- } \\
\text { Airport } \\
\text { Employees }\end{array}$ & $\begin{array}{l}\text { Operating } \\
\text { Entity } \\
\text { Employment } \\
\text { /Full Time }\end{array}$ & $\begin{array}{l}\text { Operating } \\
\text { Entity } \\
\text { Employment } \\
\text { /Part Time }\end{array}$ \\
\hline N Valid & 196 & 196 & 196 \\
Mean Missing & 63 & 63 & 63 \\
Median & 359.64 & 14.60 & 2.12 \\
Mode & 100.00 & 5.00 & 1.00 \\
Minimum & 100 & 1 & 0 \\
Maximum & 0 & 0 & 0 \\
Sum & 5000 & 542 & 26 \\
\hline
\end{tabular}

Figure 12. Statistics Outlier Removed 
The estimates using these means are: total on-airport employment 99,979, operating entity part-time employment 556, and operating entity full-time employment 4,058. The sum of these estimates is 104,593 on-airport employees.

\section{CONCLUSIONS}

The purposes of this study were:

1. To conduct a literature review of reliever airports with a focus on historical reliever airport funding, including the importance of reliever airports and reliever airport employment. The literature review assessed the economic impacts of reliever airports in order to discover what information is available to policy makers regarding the importance of reliever airports from an employment perspective.

2. To conduct a survey of reliever airports to determine:

A. The total number of employees directly employed by the operating entities that operate reliever airports; and,

B. The total employment present on each reliever airports, including operating entity employment and non-operating entity employment (general aviation companies, corporate flight departments, flight training companies, etc).

The following conclusions can be reached from the literature review:

1. Reliever airports serve 28.80 percent of the nation's general aviation aircraft even though, at the most, there are only 278 reliever airports (out of a total of 19,596 airports in the nation).

2. Reliever airports have, over the years, endured scrutiny and even cutbacks in funding. In spite of that, reliever airports have been able to achieve over $\$ 100$ million a year in AIP funding in every fiscal year since 1996, with two of those years over \$200 million.

3. Reliever airports will likely be heavily impacted by the introduction and use of Very Light Jet (VLJ) aircraft.
4. In spite of the trends mentioned above, there are calls to reduce funding to reliever airports.

5. Prior to this study, there was little comprehensive data available on reliever airport employment. Some individual studies are available for specific airports, and some states have conducted state-wide studies, but no national study of employment at reliever airports was identified in the literature review.

6. Bureau of Labor Statistics data in the NAICS category of "Airport Operations" is generalized and includes airport, airline, and general aviation data. Data on categories of airports, whether they might be hub airports or reliever airports, could not be specifically identified. However, it is clear that, with 95,489 total on-airport employees reported in this survey, the 68,100 reported in NCAIS category/sector 48811 seems under reported.

The following conclusions were interpreted from the survey, based on response rate of $77.9 \%$ of reliever airports:

- There are 2,906 reported full-time operating entity employees at reliever airports.

- There are 419 reported part-time operating entity employees at reliever airports.

- There are 95,489 reported total onairport employees at reliever airports.

- The ten airports with the highest total of operating entity employees comprise $45.7 \%$ of all reported operating employees.

- The ten airports with the highest total of on-airport employees comprise $57.7 \%$ of reported on-airport employees.

- Considering there were 56 nonrespondent airports, all of the data preliminarily reported must by expected to increase if a $100 \%$ response was achieved.

- The estimate for total on-airport employment at reliever airports is 
134,752 employees, 4,100 full-time operating entity employees, and 592 part-time operating entity employees.

- The estimate for (with removal of the outlier) total on-airport employment at reliever airports is 99,979 employees, 4,058 full-time operating entity employees, and 556 part-time operating entity employees.

\section{RECOMMENDATIONS}

In compiling this research, the authors identified the following areas of investigation related to reliever airports:

1. More attention should be given to the issues related to, and the roles of, privately- owned reliever airports since they comprise a fairly large portion of the responses to this survey; considering private operating entities represent $13.2 \%$ of all surveys received, this category should be represented in future studies.

2. Further study of the different operating entities and how they approach the operation, support and economic impact of reliever airports is worthy of study.

3. With more questions now being raised about airport funding levels in the nation, reliever airports as a category deserve further study relative to their positive impacts and value to the national air transportation system.

4. More study should be given to the relationship between operational measures (such as based aircraft, itinerant operations and total operations) and employment measures in determining the value of reliever airports.

5. Additionally, further study of the impact of new aircraft, such as VLJs, is necessary in forecasting development for reliever airports. 


\section{REFERENCES}

Airport and Airway Development Act Amendment. (1976). P.L. 94-353.

Airport and Airway Development Act of 1970. (1970). P.L. 91-258.

Airport and Airway Improvement Act of 1982. (1982). P.L. 97-248.

Airports Council International-North America. (2002). The economic impact of U.S. airports. Retrieved April 15, 2006, from http://www.aci-na.org/docs/us econ impact.pdf.

Arizona Department of Transportation Aeronautics Division. (2004, May). Economic impact of aviation in Arizona. Retrieved April 22, 2006 from http://www.dot.state.az.us/aviation/development/ PDF/Economic_Impact_of_Aviation_in_AZ_02-03.pdf.

Bonnefoy, P. A., \& Hansman, R. J. (2005). Implications of very light jets for the air transportation system. Retrieved November 16, 2006 from http://web.mit.edu/airlines/www/boardmeetings/meeting-nov-2005/Bonnefoy-Very_Light_Jets.pdf.

California Department of Transportation. (2003). Aviation in California, benefits to our economy and way of life. Retrieved April 25, 2006 from http://www.dot.ca.gov/hq/planning/ aeronaut/documents/2003EconomicStudy.pdf.

CRS Report for Congress. (2006). Reauthorization of the Federal Aviation Administration: Background and issues for Congress. Order Code RL33698.

Federal Aviation Administration. (2006). Air traffic bulletin. Retrieved October 27, 2006 from http://www.faa.gov/airports airtraffic/air traffic/publications/bulletins/media/atb sept 06.pdf.

Federal Aviation Administration. (2005). FAA aerospace forecasts: Fiscal years 2006 - 2017. Retrieved from http://faa.gov/data_statistics/aviation/aerospace_forecasts/2006-2017/media/FAA\%20 Aerospace\%20Forecast.pdf.

Federal Aviation Administration. (2005). Airport improvement program handbook. (FAA Order 5100.38b Change 1). Retrieved April 25, 2006 from www.faa.gov/airports_airtraffic/airports/aip/ aip_handbook/.

Federal Aviation Administration. (2005). AIP overview. Retrieved April 25, 2006 from http://www.faa.gov/airports airtraffic/.

Federal Aviation Administration. (2004). Report to Congress - National plan of integrated airport systems (2005-2009). Retrieved February 20, 2006, from http://www.faa.gov/ arp/planning/npias/npias2005/NPIAS2005Narr.pdf.

Federal Aviation Administration. (1998). Sixteenth annual report of accomplishments. Retrieved February 20, 2006 from: http://www.faa.gov/arp/app500/annrep97/97arc128.pdf.

Federal Aviation Administration. (1996). Grant histories. Retrieved April 5, 2006 from http://www.faa.gov.

GCR \& Associates. (n.d.). Airport IQ 5010: Airport master records and reports. Form 5010-1 information. Retrieved April 13, 2006, from http://www.gcr1.com/5010web/REPORTS/ AFD04132006MRI.pdf.

Gillis, C. (2005). Economic impact model: general aviation airports. Retrieved February 19, 2007 from http://www.aaae.org/_pdf/_regpdf/NonHub_GA4.pdf.

Jamison, A. (2004). The economic impact of Illinois airports. (Available from the Illinois Department of Transportation, Division of Aeronautics, One Langhorne Bond Drive, Capital Airport, Springfield, IL 62707). 
Minnesota Department of Transportation. (2006). Economic impact calculator. Retrieved April 25, 2006 from http://www.dot.state.mn.us/.

NewMyer, D. A. (1983, October). Problems and prospects for the growth of reliever airports. Airport Services Management, 28-32.

NewMyer, D. A., Korir, K., \& Mehta, H. (2005, April). Employment at commercial service airports in the USA: survey results.

Page, S. N. (2005, January/February). Do you have enough staff? An update (Part 2 of 2). Airport Magazine, 18-19.

Page, S. N. (2004, November/December). Do you have enough staff? An update (Part 1 of 2). Airport Magazine, 24-25.

Palwaukee Municipal Airport. (2006). Airport information. Retrieved April 25, 2006 from http://www.palwaukee.org.

Reno-Tahoe International Airport. (2006). Airport information. Retrieved April 25, 2006 from http://www.renoairport.com.

The Ohio State University Airport. (2006). Airport information. Retrieved April 25, 2006 from http://www.osuairport.org.

United States Bureau of Labor Statistics, (n.d.). Quarterly census of employment and wages-NAICS Code 48811. Retrieved April 21, 2006, from http://data.bls.gov/PDQ/outside.jsp?survey=en.

United States Census Bureau. (n.d.). 48811 Airport operations. Retrieved April 21, 2006, from http://www.census.gov/econ/census02/naics/sector48/48811.htm.

United States Census Bureau. (n.d.). 488119 Airport operations. Retrieved April 21, 2006, from http://www.census.gov/econ/census02/naics/sector48/48811.htm.

United States Department of Transportation. (1972). National airport system plan FY 1973-1982. Washington DC: Federal Aviation Administration.

United States Department of Transportation. (1966/67). National Airport Plan FY 1968-1972. Washington DC: Federal Aviation Administration.

United States Department of Transportation. (1968). National Airport Plan FY 1969-1973. Washington DC: Federal Aviation Administration.

United States Department of Transportation. (1985). National plan of integrated airport systems 1986-95. Washington DC: Federal Aviation Administration.

United States General Accounting Office. (1994). Airport improvement program, reliever set-aside funds could be redirected. (GAO Publication No. GAO/RCED-94-226). Washington DC: Author.

United States General Accounting Office. (1996). Airport improvement program: military airport program and reliever set-aside update. (GAO Publication No. GAO/RCED-94-226). Washington DC: Author.

United States Government Printing Office. (2000). Wendell H. Ford investment and reform act for the $21^{\text {st }}$ century. (P.L. 106-181). Retrieved April 5, 2006 from http://frwebgate.access.gpo.gov/ cgibin/getdoc.cgi?dbname=106_cong_public_laws\&docid=f:publ181.106.pdf. 


\section{APPENDICES}

\section{Appendix A: Sample of Survey}

\section{Airport Employment Survey}

The purpose of this research is to update a study of aviation employment that was completed in 2003. One aspect of the research is to obtain an estimate of employment at reliever airports in the USA. If you wish your airport's employment numbers to remain confidential, please inform us so that we may protect that confidentiality. In any case, Southern Illinois University Carbondale will not publish the names of those contacted for this survey.

1. Job title of person completing survey:

2. Airport name and associated city:

3. What is the operating entity of the airport?
A. City
B. County
C. Port District or Authority
D. Airport District or Authority
E. State
F. Other, please specify:

4. What is the total number of employees (at the airport) employed by the entity that operates the airport?

Full-time employees:

Part-time employees:

5. What is the total number of employees working at the airport (ALL employees, including those employed by airlines, FBOs, concessions, etc.)?

6. Comments:

Dr. David A. NewMyer

Professor and Chair

Department of Aviation Management and Flight

Southern Illinois University Carbondale

College of Applied Sciences and Arts

Mailcode 6623

Carbondale, IL 62901-6623

Phone: 618/453-8898

Fax: 618/453-7286

newmyer@siu.edu 